
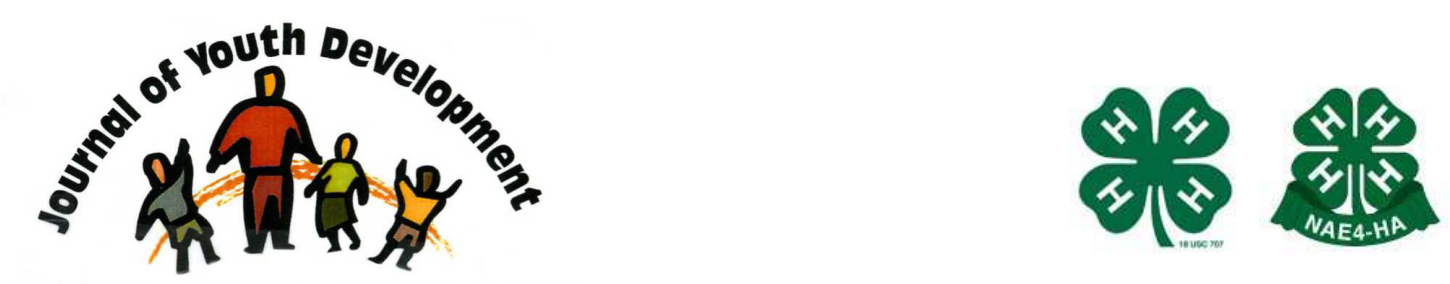

Bridging Research \& Practice

\title{
Addressing the Issue: Bullying and LGBTQ Youth
}

\author{
Kimberly Allen
}

Dept. 4-H Youth Development and Family \& Consumer Sciences

North Carolina State University

Raleigh, NC

kimbely allen@ncsu.edu 


\title{
JOURNAL OF YOUTH DEVELOPMENT \\ bridging research and practice

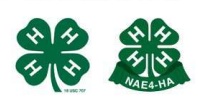

Volume 9, Number 3, Fall 2014

Article 140903FA004

\section{Addressing the Issue: Bullying and LGBTQ Youth}

\author{
Kimberly Allen \\ North Carolina State University
}

\begin{abstract}
Each day, thousands of youth experience bullying and as many of $70 \%$ of all youth report having experienced bullying, either directly or indirectly (Cantor, 2005). For Gay, Lesbian, Bi-sexual, Transgender and Questioning (LGBTQ) youth, the chances of experiencing bullying are much higher than for youth in the general population (Russell, Horn, Kosciw, \& Saewyc, 2010). Although many youth serving organizations have begun to address the issue of bullying with bullying prevention programs, there is a deficit of information and a lack of inclusion of prevention efforts that specifically address LGBTQ youth. This article addresses the role of youth organizations in creating safe and inclusive environments for all youth, with specific attention paid to resources and strategies for inclusive environments for LGBTQ youth.
\end{abstract}

\section{Introduction \\ Bullying and the Role of Youth Organizations}

Bullying is a timely topic that is gaining increased attention from main-stream media, legislators and parents alike. Convinced that bullying is not an education problem or a health problem but a community problem - President Obama \& the First Lady hosted a White House Conference on Bullying Prevention in March, 2011. Since then, the U.S. Department of Education has released an analysis of State Bullying Laws and Policies. Out of the 46 states with anti-bullying laws in place, 36 have provisions that prohibit cyber bullying and 13 have statutes that grant schools the authority to address off-campus behavior that creates a hostile school environment. There are two proposed federal education laws, The Safe Schools Improvement Act (introduced in 2010) and the Student Non-Discrimination Act (introduced in 2011) that would provide protection to populations most at risk of being targeted for bullying (Russell, Horn, Kosciw, \& Saewyc, 2010).

In addition to federal laws and policies, youth organizations, schools, and communities are also working to create more inclusive environments. Although bullying impacts all youth, there are subsets of youth that are more vulnerable for being targets of bullying (Allen, Roper \& Lewis, 
2012). Youth that are different tend to be the most vulnerable--this includes youth with disabilities or physical characteristics outside the norm, religious minority youth, and sexual minority youth. In fact, LGBT youth report regular experience with school violence (Kosciw, Greytak, Diaz \& Bartkiewicz, 2010). Reports show that Gay, Lesbian, Bi-sexual, Transgender and Questioning (LGBTQ) youth are much more likely to be targets of bullying, and the results of those negative experiences can lead to negative outcomes such as lower academic success (Murdock \& Bolch, 2005) and poor mental health outcomes (Hershberger \& D'Augelli, 1995).

Laws and policies are not enough; youth development organizations and youth professionals must come together and create a culture of inclusion and acceptance. Youth development leaders, particularly leaders in out of school youth development organizations, can and should consider creating and implementing bully prevention policies and programs within their organizations, and those organizations need to connect with other organizations, parents, community members to create a comprehensive approach to bully prevention. Unfortunately, however, there is a major gap of information for youth serving professionals on how to help vulnerable youth.

\section{Positive Youth Development (PYD)}

Youth development programs offer many protective factors for youth, but there is still work to be done, particularly on the issue of bullying and vulnerable audiences. Programs that utilize PYD already have an infrastructure that puts them in a great place to implement bullying prevention strategies for all youth, including LGBTQ youth. For example, PYD Programs typically use the Five Cs model of youth development-- competence, confidence, connection, character \& compassion with the sixth c of contribution which has started to be included as well (Lerner, 2004). These Five Cs can be found in a variety of out of school youth serving organizations, such as 4-H, Boys and Girls Clubs, and Scouts.

The Five Cs could be the very components needed to reduce the amount of bullying behaviors in youth organizations. Imagine an organization where youth gain competence in bullying prevention strategies, confidence enough to be more than a bystander-to be a leader that has character and compassion that leads to bullying prevention. Being in an inclusive Positive Youth Development organization that focuses on inclusion will help youth connect with those different from them, igniting the passion for contribution in creating a kinder, braver world.

\section{Bullying Prevention Programs and LGBTQ Youth}

Youth professionals and youth serving organizations can and are making a difference. Bullying prevention programs have now been in existence enough to have been rigorously evaluated and research on the issue of bullying prevention programs has exploded in the past decade (Allen, Roper \& Lewis, 2012b). It is now clear that particular elements are needed to create a comprehensive bullying prevention program. In a recent comprehensive review of bullying prevention research, five critical components of bullying prevention programs were identified. (Allen, Roper \& Lewis, 2012a). The 5 most critical elements in prevention programs include:

- Multi-tiered prevention approaches

- Community-based, multi-environment prevention activities

- Involving families

- Integrating and sustaining prevention efforts

- Creating or fortifying programs with prevention components for vulnerable targets 
Although each of the these critical components can be found in many evidence based programs, there is a special need for information on how to fortify programs for audiences most likely to be targeted for bulling, including religious minorities, youth with disabilities, and LGBTQ youth (Allen, et al., 2013). Although all youth are at risk for being targets of bullying behaviors, children who are unique in one way or another within a peer group may be more vulnerable to bullying. Youth that are "different" are most likely to be targeted and least likely to be specifically included in bully prevention efforts. Professionals need special training and information to address the most vulnerable youth (Bradshaw, Waasdorp, O'Brennan, \& Gulemetova, 2011).

Ideally, youth organizations would implement bullying prevention programs that include interventions and examples based specifically on youth from vulnerable populations, yet in a comprehensive review of bullying prevention programs, Allen, Roper and Lewis (2012) found that only four curricula exist that address vulnerable populations. Of those, only one addresses the specific vulnerable population of LGBTQ youth.

An additional problem that has been identified is a need for training of adults on how to address bullying of LGBTQ youth. Youth professionals report feeling discomfort and a lack of information about how to intervene when the bullying behaviors are specific to groups most at risk for being targeted, such as LGBTQ youth (Bradshaw, Waasdorp, O'Brennan \& Gulemetova, 2011). These youth need extra protection, but the youth organizations simply do not have adults in charge with the skills or comfort level to intervene.

Many evidence-based curricula provide an impact in preventing bullying behaviors in youth. However, there is a significant gap in youth organizations that address prevention components for LGBTQ youth. Now is the time for youth organizations to take a stand to address bullying behaviors for vulnerable youth. Although there is a deficit of curricula that address these vulnerable populations, there are promising practices and resources that youth professionals can use to help these youth.

\section{Best practices in bullying prevention for Gay, Lesbian, Bisexual, Transgender and Questioning (LGBTQ) Youth}

Youth organizations first need to help their employees understand the experience of vulnerable youth. Even without being a direct target of homophobic bullying, LGBTQ students report feeling isolated from friends and teachers because of the anti-gay attitudes and behaviors present in some organizations. A recent nationwide survey of LGBT youth reports that $84.6 \%$ of LGBT students reported being verbally harassed, and $40.1 \%$ reported being physically assaulted at school in the past year because of their sexual orientation (Kosciw, Greytak, Diaz \& Bartkiewicz, 2010). Furthermore, LGBTQ frequently hear homophobic remarks in school, such as "faggot," "dyke," or "queer" from students, faculty or school staff. These acts of bullying, and in some cases acts of harassment, are harmful and cause a variety of risk factors for youth.

There are steps that youth serving organizations can take to help all youth live in a kinder and braver environment. The first step in creating a more inclusive environment is to create a formal policy in which any and all incidents of harassment or bullying are documented and parents are notified. Too often, families learn of bullying incidents well after they occur. Youth often feel hesitant to tell their parents about incidents of bullying. Clear policies and procedures are important for students, as their families may not otherwise become aware of incidents. Reporting requirements should be part of a universal policy because part of the nature of 
bullying is that a youth that has been the targeted for bullying may blame him or her self or be too ashamed to report what happened.

Equally important is to teach youth to respect others without judgment. Children can begin to learn at an early age to resist bias and to value the differences and similarities between people. The Office for Civil Rights (OCR) and the Department of Justice (DOJ) have made a public effort to share that bullying may also be considered harassment when it is based on a student's race, color, national origin, sex, disability, or religion. Youth leaders should make sure all youth in their care understand that harassing behaviors may include:

- Unwelcome conduct such as verbal abuse, name-calling, epithets, or slurs

- Graphic or written statements

- Threats

- Physical assault

- Other conduct that may be physically threatening, harmful, or humiliating

GLSEN (Gay, Lesbian and Straight Education Network), a leading national education organization focused on ensuring safe schools for all students, recommends four approaches to address bullying behaviors specifically directed at LGBTQ youth based on the work of Russell, Kosciw, Horn and Saewyc (2010).

1. Youth organizations must create bullying prevention policies and procedures that specifically include language about LGBTQ youth. Research shows that youth organizations with such policies are better for LGBTQ youth. When youth are in an environment with a clear anti-LGBTQ policy, they experience fewer homophobic remarks, lower levels of harassment and assault and ultimately, they had fewer suicidal attempts (Goodenow, Szalacha, \& Westheimer, 2006; Kosciw, et al., 2010).

2. Train all adults that have contact with youth (youth leaders, teachers, bus drivers, parent volunteers, etc) on how to intervene when homophobic teasing or harassment occurs. Again, research shows that students feel safer when the adults in their environment intervene to stop harassment (O'Shaughnessy, Russell, Heck, Calhoun, \& Laub, 2004). Youth professionals are much more likely to intervene if they have had training specifically on LGBTQ bullying prevention (Greytak, \& Kosciw, 2010).

3. Create youth organized-based support groups or clubs (e.g., gay-straight alliances (GSAs). Youth in organizations with GSAs were more supportive and LGBTQ youth reported fewer sexuality related insults. GSA were also related to school attendance; youth were less likely to miss school because of feeling unsafe (Kosciw, et al., 2008). This step also fits well with the five Cs of positive youth development; students that participate in GSA groups gain competence, confidence, connection, character \& compassion. Building gay/straight relationships is critical as heterosexual youth that report having a homosexual friend were less likely to tolerate unfair treatment toward LGBTQ peers (Heinze, \& Horn, 2009).

4. Include LGBTQ role models and examples in training and instruction resources for adults and youth. Research shows that youth feel safer when they know where to get information and resources for LGBTQ or when they know who they can talk to about these issues (O'Shaughnessy, et al., 2004). 


\section{Additional programs, networks, and resources:}

The research and resources for programs for building inclusive environments for LGBTQ youth are growing. These following websites can be used to gain more information about working with and serving LGBTQ youth.

- Welcoming Schools s is a program for administrators, educators, and parents/guardians who want to strengthen their organization's approach to family diversity, gender stereotyping and bullying, and help prepare this and future generations of children to live in an increasingly diverse society.

- COLAGGE is a national movement of children, youth, and adults with one or more LGBTQ parent/s to promote social justice through youth empowerment, leadership development, education, and advocacy.

- Gay, Lesbian and Straight Education Network (GLSEN) seeks to develop school climates where difference is valued for the positive contribution it makes to create a more vibrant and diverse community.

- It Gets Better Project - is an Internet-based project which works to prevent suicide among LGBTQ youth by having gay adults convey the message that these teens' lives will improve.

- Matthew Shepard Foundation offers varied educational, outreach and, advocacy programs.

- Parents, Families and Friends of Lesbians and Gays (PFLAG) 臣 is a national grassroots program with resources for supporters of LGBTQ youth.

- The Trevor Project ; provides crisis intervention and suicide prevention services to lesbian, gay, bisexual, transgender, and questioning youth.

- Kids Included Together (KIT) provides best practices for inclusion trainings for youth organizations

\section{Implications}

Youth development organizations have a rich history of providing positive youth development programs that benefit youth. However, recently there has been some debate in the press about inclusion of LGBTQ youth and adults in youth programming. If youth development organizations are going to support youth, they need to have policies and procedures in place for all youth, especially youth most vulnerable for negative experiences. Youth professions need to familiarize themselves with the laws and policies of student non-discrimination in their state. Many states have policies that specifically prohibit discrimination on the basis of sexual orientation.

Creating inclusive environments for vulnerable youth help in the protection of all youth from bullying and harassment (Russell, Horn, Kosciw, \& Saewyc, 2010). Taking steps to ensure that youth are safe will require time, effort and training. Many adults report that they have limited knowledge or experience with preventing or intervening on bullying issues for specific audiences such as LGBTQ youth (Bradshaw, Waasdorp, O'Brennan, \& Gulemetova, 2011), but there are resources available to help train staff and students so that they can work together to create a safe environment (Allen, Lewis, \& Roper, 2012b). Inclusive policies help create supportive environments, which helps build youth wellbeing. In essence, creating bullying prevention programs that are specifically inclusive of LGBTQ youth will foster positive youth development for all youth. 


\section{Conclusion}

Youth Development organization are great for kids; they act as protective factors for a whole host of negative risk behaviors, yet there is a deficit of information and resources specifically for working with LGBTQ youth. Youth development professionals can and must work together to help reduce bullying against LGBTQ communities, but they first need promising practices to do so. In order to create safe and inclusive environments for LGBTQ youth, organizations must have policies and procedures, training for adults and youth, and supportive groups for youth. Inclusion of LGBTQ youth and resources are important for the youth and adults. With the inclusion of efforts outlined in this paper, youth serving organizations can go one step further, and can be the difference for all youth, including LGBTQ youth.

\section{References}

Allen, K., Lewis, C. \& Roper, R. (2012b). Bully prevention: Implications for youth professionals. Journal of Youth Development. 7(3), 67-78.

Allen, K., Lewis, C., \& Roper, R. (2012a) Creating safe and inclusive youth environments: A guide to bullying prevention programs. A report for the National 4-H Council. Retrieved from www.4-H.org.

Bradshaw, C.P., Wassdorp, T.E., O'Brennan, L.M., \& Gulemetova, M. (2011). Findings from the National Education Association's nationwide study of bullying: Teachers' and education support professionals' perspectives. National Education Association. Retrieved from:

http://www.nea.org/assets/img/content/Findings from NEAs Nationwide Study of Bullying.pdf

Cantor, A.S. (2005). Bullying at school. Principal, 85(2), 42-45.

Goodenow, C., Szalacha, L., \& Westheimer, K. (2006). School support groups, other school factors, and the safety of sexual minority adolescents. Psychology in the Schools, 43(5), 573589.

Greytak, E.A., \& Kosciw, J.G. (2010). Year one evaluation of the New York City Department of Education Respect for A// training program. New York: GLSEN.

Heinze, J.E., \& Horn, S.S. (2009). Intergroup contact and beliefs about homosexuality in adolescence. Journal of Youth and Adolescence, 38(7), 937-951.

Hershberger, S.L., \& D'Augelli, A.R. (1995). The impact of victimization on the mental health and suicidality of lesbian, gay, and bisexual youths. Developmental Psychology, 31(1), 65-74.

Kosciw, J. G., Greytak, E. A., Diaz, E. M., \& Bartkiewicz, M. J. (2010). The 2009 national school climate survey: The experiences of Lesbian, Gay, Bisexual and Transgender youth in our nations schools. A report from the GLSEN. Retrieved from:

http://pennsec.org/wp-content/uploads/2011/05/2009-National-School-Climate-Report-Full.pdf

Lerner, R.M. (2004). Liberty: Thriving and civic engagement among American youth. Thousand Oaks, CA: Sage. 
Murdock, T.B., \& Bolch, M.B. (2005). Risk and protective factors for poor school adjustment in lesbian, gay, and bisexual (LGB) high school youth: Variable and person-centered analyses. Psychology in the Schools, 42(2), 159-172.

O'Shaughnessy, M., Russell, S.T., Heck, K., Calhoun, C., \& Laub, C. (2004). Safe place to learn: Consequences of harassment based on actual or perceived sexual orientation and gender nonconformity and steps for making schools safer. San Francisco, CA: California Safe Schools Coalition. Retrieved from:

http://www.google.com/url?sa=t\&rct=j\&q=\&esrc=s\&source=web\&cd=1\&ved=0CFIQFjAA\&url= http\%3A\%2F\%2Fwww.nclrights.org\%2Fsite\%2FDocServer\%2FSafePlacetoLearnLow.pdf\%3Fdo cID\%3D1061\&ei=huQOUJ7MFIH48wSkm4H4DA\&usg=AFQjCNGeTP9WglJE1XRAkX05BIj8sbph6 Q

Russell, S.T., Kosciw, J., Horn S., \& Saewyc, E. (2010). Social policy report: Safe schools policy for LGBTQ students. Society for Research in Child Development, 24(4): 1-17.

(c) Copyright of Journal of Youth Development Bridging Research and Practice. Content may not be copied or emailed to multiple sites or posted to a listserv without copyright holder's express written permission. Contact Editor at: patricia.dawson@oregonstate.edu for details. However, users may print, download or email articles for individual use. 